\title{
Why Closing the Mosque: Resistance of the Indonesia's Muslim Community to the Government PPKM Policy During the Covid-19 Pandemic
}

\author{
Mustaqim Pabbajah ${ }^{1}$, Muh. Darwis ${ }^{2}$, Ashadi L Diab ${ }^{3}$, Ratri Nurina Widyanti ${ }^{4}$, Hasse Jubba ${ }^{5}$, \\ Juhansar $^{6}$, M. Taufiq Hidayat Pabbajah ${ }^{7}$, Widi Fajar Widyatmoko ${ }^{8}$, Nur Quma Laila ${ }^{9}$ \\ \{mustaqim_pabbajah@uty.ac.id ${ }^{1}$,darwis@iainpalopo.ac.id²,1diab_adhy@yahoo.com³, \\ ratri.nurina@uty.ac.id ${ }^{4}$, hasse@umy.ac.id ${ }^{5}$,juhansar@uty.ac.id ${ }^{6}$, adampabbajah@iainpare.ac.id7 \\ widifajar.psi@uty.ac.id ${ }^{8}$, nurquma2020@mail.ugm.c.id $\left.{ }^{9}\right\}$ \\ Universitas Teknologi Yogyakarta \& IA Scholar Foundation ${ }^{1}$, Institut Agama Islam Negeri, \\ Palopo $^{2}$, Institut Agama Islam Negeri, Kendari ${ }^{3}$, Universitas Teknologi Yogyakarta ${ }^{4}$, Islamic \\ Politics, Universitas Muhammadiyah Yogyakarta \& IA Scholar Foundation ${ }^{5}$, Universitas \\ Teknologi Yogyakarta ${ }^{6}$, Institut Agama Islam Negeri, Parepare ${ }^{7}$, Universitas Teknologi \\ Yogyakarta $^{8}$, Universitas Gadjah Mada \& IA Scholar Foundation, Yogyakarta ${ }^{9}$,
}

\begin{abstract}
The closure of mosques policy has become the most controversial issue during COVID-19 prevention in Indonesia. This government policy to prevent the massive transmission of COVID-19 has been considered ignoring some Muslim communities' religious values and religious understanding. This study explores the Indonesian Muslim community's pros and cons perceptions during PPKM (Enforcement of Community Activity Restrictions) implementation. It employs a qualitative descriptive approach to collect data, using observation and interviews to answer the research questions in this study. The literature study was conducted to seek data analysis concepts. This study finds various contradicted forms in understanding Islamic teachings among Muslim society during PPKM Implementation. The controversy occurs due to three factors: textual religious beliefs, habits, and the worship spirit of the Muslim community in the mosque. This condition reinforces the argument of the Muslim community, who often compares mosque closures with other places that have potential transmission of COVID-19. This condition inhibits government efforts in handling the spread of COVID-19 due to the dualism of public religious understanding, which tends to show sustenance and resistance to the implemented policy during the PPKM. Thus, an accommodative and persuasive approach involving the government, religious leaders, and community leaders is needed to handle the spread and transmission of the COVID-19 pandemic effectively.
\end{abstract}

Keywords: Mosque Closure; Resistance; Muslim Community; PPKM Policy; COVID-19

\section{Introduction}


The PPKM (Enforcement of Community Activity Restrictions) policy implemented to overcome the spread of COVID-19 has raised various community resistances. Restrictions on community socio-economic activities to the closing of worship places as stated in the Minister of Religion No. SE 17 of 2021 received the most intensive rejection during the PPKM policy. The Muslim community felt pressured due to restrictions on worship activities in mosques (Darmawan et al. 2020). The Task Force for the Acceleration of Handling COVID-19 stated that since March 2020, the government had made a multilevel, national to regional restriction policy (covid19.go.id). The policies implementations still show various forms of violations in the community, which have implications for the high rate of COVID-19 transmission in Indonesia (Pabbajah et al. 2020). The COVID-19 task force data, August 7, 2021, show that 3.6 million people confirmed positive COVID-19 (https://covid19.go.id/), even in early August 2021, Indonesia recorded the highest death case in the world due to COVID-19 (www.cnnindonesia.com). Thus, this paper presents public resistance to the PPKM policy has implications for the delay in handling COVID-19 in Indonesia.

Existing studies on community resistance concerning government policies during the COVID-19 pandemic tend to show three perspectives. First, studies seek the forms of community resistance to policies implemented during the pandemic (Harjudin 2020; Kurniawan, Yumna, and Tantri 2020; Edwards et al. 2021; Hyland et al. 2021). Second, religious responses and religious rituals during the COVID-19 pandemic (Bentzen 2020; Al Eid and Arnout 2020; Indriya 2020), the need for religious leaders and religious organizations roles to be accommodated in handling COVID-19 (Mushodiq and Imron 2020; Pabbajah et al. 2020). Third, the government policies impact multiple aspects of community survival, such as education and teaching (Almaiah, Al-Khasawneh, and Althunibat 2020; Anon 2020; Suni Astini 2020; Tria 2020), economic activities (Baldwin and Mauro 2020; Fernandes 2020; Gupta et al. 2020; Ozili and Arun 2020; Susilawati, Falefi, and Purwoko 2020), and psychological impacts (Corrigan 2020; Huang and Zhao 2020). Furthermore, Abdullah (2020) stated that PPKM policy causes fear and psychological trauma to the community.

This paper aims to complete the existing studies by focusing on the community resistance to the mosque's closure due to the PPKM policy implementation during the COVID-19 pandemic. Accordingly, three questions were asked as the focus of this study. First, what are the forms of community resistance to the mosque's closure during the implementation of PPKM. Second, what factors do encourage Muslim community resistance due to the implementation of PPKM. Third, how does the ongoing community resistance imply the handling of COVID-19 imposed by the government. These three questions are discussed sequentially in this paper.

This paper argues that public resistance will always be side-by-side with the intensity of government policies in handling COVID-19. The mosques closure refusal is considered the most controversial issue during the COVID-19 handling policy. It happens due to restrictions to the prohibition of worship activities in the mosques. At the same time, the Muslim community has a habit of worshiping in the mosque, driven by a high religious spirit. Besides, diverse religious understandings encourage the emergence of resistance. Community resistance is considered hampering the government's efforts in handling the ongoing COVID19 pandemic.

\section{Findings, Analysis, and Discussion}

2.1 The Forms of Muslim Community Resistance Due to the Mosques Closure Policy 
Due to the mosques' closure policy, several forms of resistance appear. First, Muslims still pray at the mosque, including the five daily prayers, Friday prayer, and other worship activities. Second, some people do not obey the health protocols set in praying, keeping no praying distance, and no wearing masks. Third, resistance is expressed in the form of statements or invitations to pray in the mosque. Accordingly, the mosque is a holy place. The mosque is the house of Allah, so there is no need to be afraid of COVID-19. Fourth, conveying aspirations through demonstrations, either through social media or directly by attaching banners, as a form of protest against the mosque's closure. These four forms of resistance tend to be carried out in the Muslim community to reject the mosque closure policy. A research informant stated that "I strongly reject the contents of the policy listed in point 4 regarding the closure of mosques, because mosques do not have a major contribution to the transmission and spread of COVID-19 in Indonesia" (Interview, 2021).

This assumption raises various resistances to support the argument that a mosque is not a place to spread COVID-19. Meanwhile, many other public places such as markets, shopping centers, and tourist objects are still operating. These places have the potential to become centers of the spread of COVID-19 as the informant's stated that "Why mosques must be closed, while other public places are not, such as markets, shopping centers, and tourist objects. It is unpair where many infected COVID-19 in those public places" (Interview, 2021).

Those statements represent the Muslim community response that is resistant to government policies. People tend to compare the policy of restricting activities in mosques with economic activities in the market, which respond differently (Jaya 2020). It proves that the Muslims community tends to compare activities in the market and the mosque.

\subsection{Factors Encouraging Resistance to the Restrictions of Praying in Mosques}

A mosque for Muslims functions as a means or place for conducting religious rituals and socio-religious activities. A mosque is the center of religious rituals and socialization of Muslims (Kessler 2015). A mosque is not restricted to praying, places to perform rituals, or the social and political dimensions of the Muslim community. Instead, it serves as a symbol of ownership and identity. A mosque is a central institution for the Muslim identity (Abdel-Hady 2010). In a pandemic situation, it is necessary to obey government policies so that mosques do not become places to spread COVID-19. Thus, the government and the Indonesian Ulema Council (MUI) are more recommended and prioritized following the authorities' policies. Although the policy is not mandatory, it is recommended to minimalize the transmission and the spread of COVID-19 (Hasibuan and Yusram 2020).

Praying in the mosque is a long-standing habit practiced by Muslims around the world. A mosque functions as a place of praying and as a center for socio-religious activities. A Muslim has various reasons to pray at the mosque, even though the COVID-19 situation is still ongoing. COVID-19 does not dampen the Muslims' desire to pray at the mosque for at least three factors. First, a textual understanding of Islamic teaching; for example, praying in the mosque has more reward than home. Praying in the mosque is conducted to keep in touch with other Muslims. These two things are the main factors for a Muslim to pray in the mosque as stated by the informant's that "Actually, we are praying in the mosque because it has much more rewards than praying at home" (Interview, 2021).

Second, social media and electronic media information about COVID-19 influence public perceptions. The two media are a means of producing and consuming public knowledge. Discussions about COVID-19 have spread rapidly on the Internet and quickly become the focus of world attention (Zhao and $\mathrm{Xu} 2020$ ). Social media is rapidly becoming the fastest 
communication tool for creating, disseminating and consuming COVID-19 information (Tsao et al. 2021). The spread of health protocol misinformation promotes mispractices that increase the spread of the virus and ultimately result in poor physical and mental health outcomes among individuals (Tasnim, Hossain, and Mazumder 2020). Thus, intensive and comprehensive socialization is needed to build public knowledge to avoid hoaxes. Integrated socialization, central to regional levels as well as national to local levels, is required.

Third, the public considers that the government is slow to handle the COVID-19 pandemic, which is less sensitive to reality. It harms various life sectors of society. The government policy in determining priorities for evidence-based interventions becomes substantial (Saputra and Salma 2020). Thus, COVID-19 policies socialization has not been appropriately conveyed. It causes targets-achieved experiencing obstacles, moreover resistances. It indicates that the COVID-19 pandemic creates an urgent need for governments to address these limitations (Mali, Yerramsetti, and Manoharan 2020). As a result, the government implemented the Large-Scale Social Restriction (PSBB) policy to reduce the spread of COVID-19. However, people whose livelihoods are in the informal sector find difficulties in fulfilling their daily needs. Therefore, the government should be more concerned about the lives of lower-class people (Nasruddin and Haq 2020). It means that local governments in making policies need to be synchronized with the central and regional government's policies (Nurfurqon 2020). In other words, the policies taken should not overlap between the center, the regions, and the local interests of each area.

The policy is a strategic decision that needs to be taken in response to the conditions experienced by each region. Deni et al. (2020) define public policy as a decision to bind many people at a strategic level made by public authorities. Thus, public policy deals with laws, regulations, governance mechanisms, and general management guidelines to assist the government (Andriansyah, Taufiqurokhman, and Wekke 2019). The lens of public authority reveals micropolitical practices carried out by non-state and state actors in the bureaucracy, judiciary, politics, markets, and others who use "remote control" (te Lintelo 2017). Based on the legal awareness concept, the disobedience of street vendors to the law is not only a coping mechanism to participate in the economic system but also a weapon for the weak to voice their ideas and opinions about the injustice of the political and economic system in which they live (Vargas and Urinboyev 2015). As a result, ideology polarization becomes one of the participation conflict sources in a country, which brings government-trust decrease (Jubba et al. 2019). Correspondingly, in Croatia, participation in the informal economy results from the asymmetry between the norms, values, and beliefs of citizens (informal institutions), codified laws and regulations (formal institutions) (Williams and Franic 2016).

\subsection{Implications of Resistance to Handling COVID-19}

James Scoot uses the concept of resistance to see community resistance (Pabbajah 2020). Scott (2017) divides the resistance into two parts; public transcript and hidden transcript. In this context, resistance means a protest to changes that occur and are not under religious values (Sumbulah 2014) or the religious practice, which is different from mainstream perspectives (Pabbajah et al. 2019). Likewise, the prayer response in the mosque policies needs to be handled well during the pandemic (Jubba 2021). The relationship between "the weak" and "the strong" is actually in an unequal power relationship, so "the weak" as the lower structure tries to balance their relationship through resistance for being not to be oppressed (Broadhurst et al. 2015; Green and Ward 2012; Roy 2011a, 2011b). 
Resistance also has implications for hampering efforts to deal with COVID-19 as a whole. This paper shows at least three implications. First, the increase of intense community resistance impacts the delayed handling of COVID-19. The existence of resistance is reinforced by the differences in way and perspective between the central and local governments in handling the spread of COVID-19, which tend to lead to conflict in the community (Fakhruroji et al., 2019). The problem is that the government finds it difficult to convince and make people aware of the importance of obeying health protocols during a pandemic. Instead, what seems dominant is the resistance due to public distrust with various pandemic policies (Harjudin 2020).

Second, the resistance to the PPKM policy to suppress the spread of the COVID-19 resulted in its spread massively. The previous discussion shows that public non-compliance with the PPKM policy limiting praying activities in mosques has terrible implications for the expected Covid-19 suppression efforts. Although various efforts were implemented, such as religious approaches through Islamic religious educators, the spread of COVID-19 still grows massively. It proves that cooperation and the awareness of all parties are needed (Sugara and Ulfa 2021). In other words, resistance to the PPKM policy only raises new problems in handling the spread of COVID-19.

Third, the resistance to the PPKM policy implies the worsening image of mosques in particular and Islam in general, which seems not to care about the spread of COVID-19. The mosque as a holy place for Muslims seems to reject the policy of the common good. In contrast, Islam teaches to prioritize the benefit of humans as a whole, beyond the interests of groups and religions (Hannan and Muhaimin 2020; Harisah 2020). Resistance also shows the weakness of religious authority due to Muslim figures who do not believe in COVID-19 and consider it a conspiracy. It is a form of deauthorization of the ulama as the role model of the Muslims (Pabbajah et al. 2020). Those resistance implications hinder the government's efforts in dealing with COVID-19 and result in the waning of harmonization relations of communities horizontally (see appendix).

\section{Conclusion}

The PPKM policy still raises various controversial responses in the community. The high level of COVID-19 spread proves disobedience of health protocols in many places. This paper shows public resistance to PPKM policies regarding restrictions to mosques closure. Three essential findings of this study confirming resistance. First, the emergence of various forms of resistance, such as praying in the mosque and other socio-religious activities by ignoring health protocols. Second, factors encouraging resistance to the restrictions of praying in mosques are driven by the habit of Muslims praying at a mosque to get more rewards. Third, the implications of resistance at least impact the delayed handling of COVID-19. The spread of COVID-19 is increasingly widespread with high intensity. It proves the weakness of religious authority.

This paper relies on the theory of resistance as an analytical perspective to answer research questions and explain the community's condition in responding to government policies during the COVID-19. The limitation of this paper lies in the minor source of informant and study focus. It focuses on discovering forms, factors, and implications of the resistance of the Muslim community to the mosque's closure subjectively. It does not represent the objective conditions of the diversity of Indonesian people's responses to the policies implemented. 
Therefore, this paper recommends a further study with a contextual concept approach supported by comprehensive data.

\section{Acknowledgements}

All authors are permanent lecturers at various universities in Indonesia and this article supported by IA Scholar Foundation.

\section{References}

[1] Abdullah, Irwan. 2020. "COVID-19: Threat and Fear in Indonesia." Psychological Trauma: Theory, Research, Practice, and Policy.

[2] Almaiah, Mohammed Amin, Ahmad Al-Khasawneh, and Ahmad Althunibat. 2020. "Exploring the Critical Challenges and Factors Influencing the E-Learning System Usage during COVID-19 Pandemic.” Education and Information Technologies.

[3] Andriansyah, Andriansyah, Taufiqurokhman Taufiqurokhman, and Ismail Suardi Wekke. 2019. "Responsiveness of Public Policy and Its Impact on Education Management: An Empirical Assessment from Indonesia." Management Science Letters.

[4] Anon. 2020. "Impact of Coronavirus Pandemic on Education." Journal of Education and Practice.

[5] Baldwin, Richard, and Beatrice Weder di Mauro. 2020. Economics in the Time of COVID-19.

[6] Bentzen, Jeanet Sinding. 2020. "In Crisis, We Pray Religiosity and the COVID-19 Pandemic." Covid Economics.

[7] Broadhurst, Roderic, Thierry Bouhours, Brigitte Bouhours, Roderic Broadhurst, Thierry Bouhours, and Brigitte Bouhours. 2015. "Resistance of a Peasant Society." Pp. 35-53 in Violence and the Civilising Process in Cambodia.

[8] Corrigan, Patrick. 2020. "On the Stigma of COVID-19.” Psychology Today 1-6.

[9] Darmawan, Dadang, Deni Miharja, Roro Sri Rejeki Waluyajati, and Erni Isnaeniah. 2020. "Sikap Keberagamaan Masyarakat Menghadapi Wabah COVID-19." Religious: Jurnal Studi Agama-Agama Dan Lintas Budaya.

[10] Deni, S., T. Husain, and A. Deni. 2020. "Bureaucracy and Challenges in Digital Era: A New Concept of Information Technology Integration in the Archipelagic Country." Journal of Public Policy.

[11] Edwards, Ben, Nicholas Biddle, Matthew Gray, and Kate Sollis. 2021. "COVID-19 Vaccine Hesitancy and Resistance: Correlates in a Nationally Representative Longitudinal Survey of the Australian Population." PLOS ONE.

[12] Al Eid, Nawal A., and Boshra A. Arnout. 2020. "Crisis and Disaster Management in the Light of the Islamic Approach: COVID-19 Pandemic Crisis as a Model (a Qualitative Study Using the Grounded Theory)." Journal of Public Affairs.

[13] Fakhruroji, Moch, Betty Tresnawaty, A. S. Haris Sumadiria, Enok Risdayah, and Kata Kunci. 2019. "Strategi Komunikasi Publik Penanganan COVID-19 Di Indonesia: Perspektif Sosiologi Komunikasi Massa Dan Agama.” Ilmu Komunikasi UIN Sunan Gunung Djati Bandung 1(1):1-11.

[14] Fernandes, Nuno. 2020. "Economic Effects of Coronavirus Outbreak (COVID-19) on 
the World Economy." SSRN Electronic Journal.

[15] Green, Penny, and Tony Ward. 2012. "Civil Society, Resistance, and State Crime." Pp. 28-40 in State Crime and Resistance.

[16] Gupta, Mrinal, Ayman Abdelmaksoud, Mohammad Jafferany, Torello Lotti, Roxanna Sadoughifar, and Mohamad Goldust. 2020. "COVID-19 and Economy." Dermatologic Therapy.

[17] Hannan, Abd, and Wafi Muhaimin. 2020. "Teologi Kemaslahatan Social-Phsycal Distancing Dalam Penanggulangan Covid-19.” Jurnal Kurioritas.

[18] Harisah, Harisah. 2020. "Kebijakan Pemberian Insentif Pada Tenaga Medis Virus Corona Covid-19 Pendekatan Maslahah.” SALAM: Jurnal Sosial Dan Budaya Syar-I $7(6)$.

[19] Harjudin, Laode Ode. 2020. "Dilema Penanganan Covid-19: Antara Legitimasi Pemerintah dan Kepatuhan Masyarakat.” Jurnal Kesejahteraan Dan Pelayanan Sosial.

[20] Hasibuan, Eko Misbahuddin, and Muhammad Yusram. 2020. "Hukum Salat Berjemaah Di Masjid Dengan Saf Terpisah Karena Wabah Covid-19." BUSTANUL FUQAHA: Jurnal Bidang Hukum Islam 1(2):106-24.

[21] Huang, Yeen, and Ning Zhao. 2020. "Mental Health Burden for the Public Affected by the COVID-19 Outbreak in China: Who Will Be the High-Risk Group?" Psychology, Health, and Medicine.

[22] Hyland, P., F. Vallières, M. Shevlin, R. P. Bentall, R. McKay, T. K. Hartman, O. McBride, and J. Murphy. 2021. "Resistance to COVID-19 Vaccination Has Increased in Ireland and the United Kingdom during the Pandemic." Public Health.

[23] Indriya, Indriya. 2020. "Konsep Tafakkur Dalam Alquran Dalam Menyikapi Coronavirus Covid-19.” SALAM: Jurnal Sosial Dan Budaya Syar-I 7(3).

[24] Jaya, Indra Budi. 2020. "Relasi Masjid dan Pasar: Kajian Sosiologi Hukum terhadap Kebijakan Penerapan Pembatasan Sosial Berskala Besar Saat Pandemi COVID 19.” FASTABIQ : JURNAL STUDI ISLAM.

[25] Jubba, Hasse. 2021. "Beradaptasi Dengan Bencana: Strategi Beribadah Umat Islam Dan Kristen Di Tengah Pandemi Covid-19." Religious: Jurnal Studi Agama-Agama Dan Lintas Budaya.

[26] Jubba, Hasse, Suparto Iribaram, Mustaqim Pabbajah, and Misbah Zulfa Elizabeth. 2019. "Preferensi Pemilih Muslim Milenial Pada Pemilihan Presiden-Wakil Presiden 2019.” JSW (Jurnal Sosiologi Walisongo).

[27] Kessler, Kristel. 2015. "Conceptualizing Mosque Tourism: A Central Feature of Islamic and Religious Tourism.” International Journal of Religious Tourism and Pilgrimage.

[28] Kurniawan, Andri, Nibrasatul Yumna, and Erna Tantri. 2020. "Resistensi Ruang Publik di Tengah Covid-19 Perspektif Islam dan Komunikasi Multikultural." KOMUNIKE.

[29] te Lintelo, Dolf J. H. 2017. "Enrolling a Goddess for Delhi's Street Vendors: The Micro-Politics of Policy Implementation Shaping Urban (in)Formality." Geoforum.

[30] Mali, Nidhi Vij, Srinivas Yerramsetti, and Aroon P. Manoharan. 2020. "Communicative Governance to Mitigate the COVID-19 Pandemic." International Journal of E-Planning Research.

[31] Mushodiq, Muhamad Agus, and Ali Imron. 2020. "Peran Majelis Ulama Indonesia Dalam Mitigasi Pandemi Covid-19 (Tinjauan Tindakan Sosial Dan Dominasi Kekuasaan Max Weber).” SALAM: Jurnal Sosial Dan Budaya Syar-I 7(5).

[32] Nasruddin, Rindam, and Islamul Haq. 2020. "Pembatasan Sosial Berskala Besar (PSBB) Dan Masyarakat Berpenghasilan Rendah.” SALAM: Jurnal Sosial Dan Budaya 
Syar- $I$.

[33] Nurfurqon, Ardika. 2020. “Analisis Kebijakan Pemerintah Daerah Dalam Penanganan Covid-19: Perspektif Hukum Administrasi Negara." JURNAL YUSTIKA: MEDIA HUKUM DAN KEADILAN.

[34] Ozili, Peterson K., and Thankom Arun. 2020. "Spillover of COVID-19: Impact on the Global Economy." SSRN Electronic Journal.

[35] Pabbajah, Mustaqim. 2020. "Resepsi Dan Resistensi : Respons Masyarakat Terhadap Jamaah An-Nadzir Sebagai Komunitas Muslim Di Tengah Arus Demokratisasi Di Indonesia." 4(4):251-66.

[36] Pabbajah, Mustaqim, Irwan Abdullah, Juhansar, and Hasse Jubba. 2019. "Contested Socio-religious Reality: An-Nadzir, a Non-Mainstream Islamic Movement in Indonesia." The International Journal of Religion and Spirituality in Society 9(2):7178.

[37] Pabbajah, Mustaqim, Nurhidayat Muhammad Said, M. Taufiq Hidayat Pabbajah, and Hasse Jubba. 2020. "Deauthorization of the Religious Leader Role in Countering Covid-19: Perceptions and Responses of Muslim Societies on the Ulama's Policies in Indonesia". The International Journal of Criminology and Sociology. Vol. 9.

[38] Roy, Olivier. 2011a. "Cultural Patterns and Changes in Society: An Assessment." Pp. 215-27 in Islam and Resistance in Afghanistan.

[39] Roy, Olivier. 2011b. "Society and the War." Pp. 149-71 in Islam and Resistance in Afghanistan.

[40] Saputra, Hermawan, and Nadilah Salma. 2020. "Dampak PSBB Dan PSBB Transisi Di DKI Jakarta Dalam Pengendalian COVID-19." Media Kesehatan Masyarakat Indonesia.

[41] Scott, James C. 2017. Against the Grain: A Deep History of the Earliest States.

[42] Sugara, Robi, and Maria Ulfa. 2021. "Implementasi Kebijakan Publik Dalam Penanganan Covid-19 Melalui Pendekatan Keagamaan.” Jurnal Bimas Islam.

[43] Sumbulah, Umi. 2014. “Agama, Kekerasan Dan Perlawanan Ideologis." ISLAMICA: Jurnal Studi Keislaman 1(1):1.

[44] Suni Astini, Ni Komang. 2020. "Tantangan Dan Peluang Pemanfaatan Teknologi Informasi Dalam Pembelajaran Online Masa Covid-19." Cetta: Jurnal Ilmu Pendidikan.

[45] Susilawati, Susilawati, Reinpal Falefi, and Agus Purwoko. 2020. "Impact of COVID19's Pandemic on the Economy of Indonesia." Budapest International Research and Critics Institute (BIRCI-Journal): Humanities and Social Sciences.

[46] Tasnim, Samia, Md Mahbub Hossain, and Hoimonty Mazumder. 2020. "Impact of Rumors and Misinformation on COVID-19 in Social Media." Journal of Preventive Medicine and Public Health = Yebang Uihakhoe Chi 53(3):171-74.

[47] Tria, Jose Z. 2020. "The COVID-19 Pandemic through the Lens of Education in the Philippines: The New Normal." International Journal of Pedagogical Development and Lifelong Learning.

[48] Tsao, Shu-Feng, Helen Chen, Therese Tisseverasinghe, Yang Yang, Lianghua Li, and Zahid A. Butt. 2021. "What Social Media Told Us in the Time of COVID-19: A Scoping Review." The Lancet Digital Health 7500(20):1-20.

[49] Vargas, Ana Maria, and Rustamjon Urinboyev. 2015. "Everyday Forms of Resistance to the Law: An Ethnographic Study of Street Vendors in Bogotá." Droit et Societe.

[50] Williams, Colin C., and Josip Franic. 2016. "Explaining Participation in the Informal Economy in Post-Socialist Societies: A Study of the Asymmetry between Formal and 
Informal Institutions in Croatia." Journal of Contemporary Central and Eastern Europe.

[51] Zakaryya Mohamed Abdel-Hady. 2010. "The Masjid, Yesterday and Today." The Center for International and Regional Studies 2(1-25).

[52] Zhao, Yuxin, and Huilan Xu. 2020. Chinese Public Attention to COVID-19 Epidemic: Based on Social Media.

[53] Scott, James C. 2017. Against the Grain: A Deep History of the Earliest States. Connecticut: Yale University Press 
